antibodies as well as differences in the design of the studies, the patient population, and the definition of shock.

The importance of resolving these uncertainties is highlighted by the financial implications of the universal introduction of monoclonal antibodies against endotoxin for treating suspected Gram negative sepsis and septic shock. Not only is HA-1A expensive but vast numbers of patients would fulfil even the strictest criteria for its administration: in the United Kingdom there are perhaps 25000 cases of Gram negative septicaemia each year..$^{22}$ Here expenditure on HA-1A could exceed $£ 100 \mathrm{~m}$ a year ${ }^{22}$; in the United States the annual cost could approach $\$ 1 \cdot 6 \mathrm{~b} .{ }^{23}$ These figures have caused considerable alarm, although they are likely to be overestimates and analysing the cost effectiveness of treatment with HA-1A will be important before concluding that these high costs cannot be justified. In the United Kingdom HA-1A might save between 5000 and 10000 lives a year at a cost of about $\$ 5000$ per life year saved, an amount that compares very favourably with other widely accepted medical interventions.

Some will consider that, particularly in view of the financial implications, introducing treatment with monoclonal antibodies directed against endotoxins should be delayed until confirmatory studies have been performed and some of the uncertainties resolved. Certainly those who wish to introduce HA-1A into their clinical practice on the basis of current evidence must ensure that it is not used indiscriminately. ${ }^{24}$ The decision to give HA-1A should be taken by experienced intensive care clinicians guided by strict protocols designed to maximise the likelihood of treated patients having Gram negative bacteraemia or endotoxaemia and avoid treating patients whose prognosis is hopeless.

Categories of patients in whom the efficacy of treatment with antiendotoxins has not been shown (for example those with neutropenia) should not receive it. ${ }^{24}$ The criteria used in Ziegler et al's study seem to identify patients with a $30-40 \%$ probability of having Gram negative bacteraemia, ${ }^{15}$ but increasing this proportion by more careful clinical assessment of individual cases may be possible. Clearly, the development of new techniques for reliably and rapidly diagnosing endotoxaemia and Gram negative bacteraemia would resolve many of the difficulties.

In the future it should be possible to produce monoclonal antibodies against other toxic products of infecting organisms, as well as other components of the inflammatory cascade. Treatment with a combination of monoclonal antibodies will then be feasible. Although still in its infancy, the use of monoclonal antibodies is likely to make an important contribution to improving the outcome of life threatening infections.

C J HINDS

Director of Intensive Care,

St Bartholomew's Hospital,

London EC1A 7BE

Ledingham IMcA, McArdle CS. Prospective study of the treatment of septic shock. Lance 1978;i:1194-7.

2 Espevik T, Brockhaus $M$, Loetscher $H$, Nonstad U, Shalaby R. Characterization of binding and biological effects of monoclonal antibodies against a human tumor necrosis factor receptor. $\mathcal{J}$ Exp Med 1990;171:415-26.

3 Hinshaw LB, Tekamp-Olson P, Chang ACK, Lee PA, Taylor FB Jr, Murray CK, et al. Survival of primates in $\mathrm{LD}_{100}$ septic shock following therapy with antibody to tumor necrosis factor (TNF $\alpha$ ). Circ Shoch 1990;30:279-92.

4 Tracey KJ, Fong Y, Hesse DG, Manogue KR, Lee AT, Kuo GC, et al. Anti-cachectin/TNF monoclonal antibodies prevent septic shock during lethal bacteraemia. Nature 1987;330:662-4 Exley AR, Cohen J, Buurman W, Owen R, Hanson G, Lumley J, et al. Monoclonal antibody to TNF in severe septic shock. Lancet 1990;335:1275-6.

6 Ziegler EJ, McCutchan JA, Fierer J, Glauser MP, Sadoff JC, Douglas H, et al. Treatment of Gram negative bacteremia and shock with human antiserum to a mutant Escherichia coli. $N$ Englf $\mathrm{Med}$ 1982;307:1225-30.

7 Baumgartner J-D, Glauser MP, McCutchan JA, Zeigler EJ, van Melle G, Klauber MR, et al. Prevention of Gram-negative shock and death in surgical patients by antibody to endotoxin core glycolipid. Lancet 1985;ii:59-63.

8 Schedel I, Dreikhausen U, Nentwig B, Hockenschnieder M, Rauthmann D, Balikcioglu S, et al. Treatment of Gram-negative septic shock with an immunoglobulin preparation: a prospective randomized clinical trial. Crit Care Med 1991;19:1104-13.

9 Calandra T, Glauser MP, Schellekens J, Verhoef J. Treatment of Gram-negative septic shock with human IgG antibody to Escherichia coli J5: a prospective, double-blind, randomized trial. human IgG antibody to Est Dis 1988;158:312-9.

10 McCabe WR, De Maria A Jr, Berberich H, Johns MA. Immunization with rough mutants of salmonella minnesota: prospective activity of IgM and IgG antibody to the R595 (Re Chemotype) mutant. $\mathcal{F}$ Infect Dis 1988;158:291-300.

11 Teng NNH, Kaplan HS, Herbert JM, Moore C, Douglas H, Wunderlich A, et al. Protection against Gram-negative bacteremia and endotoxemia with human monoclonal IgM antibodies. Proc Natl Acad Sci USA 1985;82:1790-4.

12 Ziegler EJ, Teng NNH, Douglas H, Wunderlich A, Berger JH, Bolmer SD. Treatment of pseudomonas bacteria in neutropenic rabbits with human monoclonal IgM antibody against $\mathrm{E}$ coli lipid A. Clin Res 1987;35:619A.

13 Khazaeali MB, Wheeler R, Rogers K, Ziegler E, Haynes A, et al. Initial evaluation of a human immunoglobulin $M$ monoclonal antibody (HA-1A) in humans. I Biol Response Mod 1990;9:178-84.

14 Fisher CJ, Zimmerman J, Khazaeli MB, Albertson TE, Dellinger RP, Panacek EA, et al. Initia evaluation of human monoclonal anti-lipid A antibody (HA-1A) in patients with sepsis syndrome. Crit Care Med 1990;18:1311-5.

15 Ziegler EJ, Fisher CJ, Sprung CL, Straube RC, Sadoff JC, Foulke GE, et al. Treatment of Gramnegative bacteremia and septic shock with HA-1A human monoclonal antibody against endotoxin. N Engl f Med 1991;324:429-36.

16 Baumgartner JD, Heumann D, Calandra T, Glauser MP. Antibodies to lipopolysaccharides after immunisation of humans with the rough mutant Escherichia coli J5. I Infect Dis 1991;163:769-72.

17 Heumann D, Baumgartner JD, Jacto-Guillarmod H, Glauser MP. Antibodies to core lipopolysaccharide determinants: absence of cross reactivity with heterologous lipopolysaccharides. F Infect Dis 1991;163:762-8.

8 Baumgartner JD, Heumann D, Gerain J, Weinbreck P, Grau GE, Glauser MP. Associatio between protective efficacy of anti-lipopolysaccharide (LPS) antibodies and suppression of LPS induced tumor necrosis factor $\alpha$ and interleukin 6. Comparison of $O$ side chain-specific antibodies and core LPS antibodies. $\mathcal{F}$ Exp Med 1990;171:889-96.

19 Baumgartner JD, Heumann D, Glauser MP. The HA-1A monoclonal antibody for Gram-negative sepsis (letter). N Engl f Med 1991;325:281-2.

20 Danner RL, Elin RJ, Hosseini JM, Wesley RA, Reilly JM, Parillo JE. Endotoxin in human septic shock. Chest 1991;99:169-75.

21 Greenman RL, Schein RMH, Martin MA, Wenzel RP, MacIntyre NR, Emmanuel G, et al. A controlled clinical trial of E5 murine monoclonal IgM antibody to endotoxin in the treatment of Gram-negative sepsis. IAMA 1991;266:1097-102.

22 Taylor D. Centoxin - birth of a budgetbuster. $B M$ I $^{2}$ 1991;302:1229.

23 Schmidt GA. The HA-1A monoclonal antibody for Gram-negative sepsis (letter). $N$ Engl f Med 1991:325:280-1.

24 Bone RC. Monoclonal antibodies to endotoxin. New allies against sepsis? FAMA 1991;266:1125-6.

\title{
FHSA medical advisers: friends or foes?
}

\section{A role with a lot of promise}

The medical advisers to family health services authorities were originally intended to help implement the indicative prescribing scheme and to provide advice on prescribing to both general practitioners and the family health services authority. ${ }^{1}$ In fact, in many authorities the medical adviser has a much wider remit. General practitioners were originally suspicious of the part medical advisers were to play in prescribing, but in the long term they may come to welcome their role in developing general practice.

Funding for "a prescribing medical adviser" in each family health services authority was provided by the Department of Health as part of the "improving prescribing" initiative, ${ }^{2}$ but managers had some discretion on how to use the funding, so that only 47 of the 124 advisers are full time and advice has also been purchased from directors of public health, academic departments of general practice, and other specialists, such as community paediatricians. The late appointment of many advisers and the early deadlines for setting indicative prescribing amounts meant that the discussion between advisers and general practitioners were less than desired by either side. 
Many general practitioners were suspicious that the chief aim of the medical adviser was to reduce expenditure on drugs and to interfere with clinical freedom. ${ }^{3}$ But rational prescribing means directing resources to where they can be used most effectively, ${ }^{4}$ and improving prescribing is not simply a matter of eliminating waste. Thus in some practices, where conditions such as asthma and hypertension may be undertreated, advisers will prompt doctors to increase their prescribing costs. ${ }^{5}$

Advising about prescribing is only part of the work of most medical advisers, and in some family health services authorities the job of providing guidance on prescribing has been delegated to pharmacist advisers. The medical advisers themselves may be overseeing health promotion, facilitating medical audit, and, in some cases, taking a management role within the authority. ${ }^{6} \mathrm{~A}$ further task, recently acquired, is monitoring the use of controlled drugs, which was formerly undertaken by the disbanded regional medical services.

Most full time medical advisers have come from general practice or from the regional medical service, while most part timers are still practising general practitioners. Some have wanted a change from general practice and a new challenge, whereas others have a powerful vision of where general practice should be going in the 1990s. All advisers will bring to the job their own experience of general practice, but they need to add new skills, including a knowledge of clinical pharmacology, ${ }^{7}$ management, and health economics. Other new skills need to be developed, such as ways of interpreting and presenting prescribing data, ${ }^{89}$ and a support centre has been introduced to meet these needs. ${ }^{2}$

At its broadest the role of medical adviser is the equivalent in general practice to that of the clinical director in hospital, with responsibilities for planning, resource allocation, service development, and standards. Those with this sort of role see themselves as bridge builders between individual general practitioners and family health services authority managers; they may also become bridge builders between hospital specialists and general practitioners in discussions over protocols for shared care.$^{10}$ As family health services authorities and district health authorities (and fundholders) clarify their roles in commissioning ${ }^{11}$ the medical adviser may act as a district specialist in primary care and form a natural link between the commissioning authority, provider units, and the regional authority. An example of this wider role is the monitoring of fundholding practices, already part of the duties of some advisers, and one that may grow with the number of fundholders.

Medical advisers have many problems to overcome, not least maintaining their accountability both to a wary profession and to family health services authority managers. They need to establish relationships with public health specialists, and full time advisers will have to preserve their clinical credibility among their general practitioner colleagues. A newly established committee of the BMA is considering terms and conditions of service, and the advisers themselves are addressing the ethical, legal, and educational issues that are part of their daily work. A crucial task for the first advisers is to develop a flexible career that provides professional fulfilment for them and their successors. ${ }^{12}$

Arguably, medical advisers fill a gap between primary care and the wider health service that has existed since the beginning of the NHS. If they fulfil their promise of becoming key figures in "maintaining and improving the health of local people"13 and in developing general practice they will be an unexpected benefit of the "Improving Prescribing" initiative.

TOM WALLEY Clinical Pharmacologist JOHN BLIGH

National Medical Advisers Support Centre, General Practice Adviser

Hamilton House,

Pall Mall,

Liverpool L3 6AL

1 Department of Health. Indicative prescribing budgets for general medical practitioners. Working paper 4. London: HMSO, 1989

2 Department of Health. Improving prescribing. London: HMSO, 1989.

3 O'Dowd TC, Wilson AD. Set menus and clinical freedom. $B M \mathcal{Y}$ 1991;303:450-2.

4 British Medical Association. Leading for health: a BMA agenda for health. London: BMA, 1991.

5 O'Brien B. Indicative drug budgets for general practitioners. $B M \mathcal{J}$ 1989;298:944-6.

6 Rous E. The role of the medical adviser at the FHSA. Br f Gen Pract 1990;49:519-20.

McGavock H. Promoting rational therapeutics: the Swedish guidelines and a UK response. $\mathrm{Br} \mathcal{J}$ Gen Pract 1990;40:1-3.

8 Harris CM, Heywood PL, Clayden AD. The analysis of prescribing in general practice. London: HMSO, 1990.

9 Forster DP, Frost CEB. The use of regression analysis to explain the variations in prescribing rate and costs between family practitioner committees. Br f Gen Pract 1991;41:67-71.

10 Shapiro J. We may never understand each other. BMF 1991;303:1138.

10 Shapiro J. We may never understand each other. BMF 1991;303:1138.

11 Foster A. FHSAs: today's and tomorrow's priorities. London: N

13 Department of Health. The health of the nation. London: HMSO, 1991.

\section{Prison medicine: beginning again}

\section{Time to hand over everything to the NHS}

Britain's new private prison is thinking about how to organise health care for its prisoners. Starting work on a blank canvas must be much more rewarding than reworking an old picture, especially one as badly botched as the prison medical service. It's most unlikely that anybody would advise the new prison to copy the existing medical service. So why shouldn't the whole system have a chance to start all over again?

The stars seem favourable for just such a dramatic development. In December the European Committee for the Prevention of Torture and Inhuman or Degrading Treatment or Punishment declared that some of the treatment received by British prisoners was inhuman and degrading. ${ }^{1}$ As a result the prison system is in deeper opprobrium than ever, and last week the chief inspector of prisons published yet another damning report on a prison, this time Canterbury; it was so dirty, cramped, and dispiriting, he said, that it was no longer fit to serve as the local prison for Kent. ${ }^{2}$ Overcrowding is now desperately bad all around the country after a $9 \%$ increase in the prison population last year. ${ }^{3}$ The Woolf report urged root and branch reform of the whole service, ${ }^{45}$ and a management report commissioned by the Home Office recommended that the prison service should become a stand alone organisation. ${ }^{6}$ An efficiency scrutiny has already recommended fundamental reform of the medical service, ${ }^{7}$ and its recommendations are inching towards implementation. Sir Donald Acheson has just been appointed the first chairman of the health advisory committee for the prison service. And-perhaps most importantly - the changes in the NHS should make it easier for it to take over responsibility for providing health care to prisoners.

Many of those who have looked at prison health careparticularly the social services committee of the House of Commons $^{8}$ - have stopped short of recommending scrapping 